\title{
A ESCOLARIZAÇÃO DE CRIANÇAS "COM DGD"1
}

\author{
Leandro de Lajonquière
}

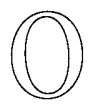

tema proposto para a aula de hoje é "a escolarização da criança com DGD". Como sabemos, segundo os parâmetros dos organismos mundiais de saúde, essa sigla significa distúrbios globais do desenvolvimento. Essa nomenclatura encobre, de certa forma, aquilo que poderia, a princípio, ser considerado como sendo o conjunto dos fenômenos próprios do campo da psicose ou do autismo na infância. Dessa forma, caberia observar que, quando nos perguntamos pela escolarizaçào de crianças com DGD, estamos, de fato, nos interrogando sobre a escolarização de crianças psicóticas ou autistas ou, em outras palavras, sobre a educação no campo da psicose e do autismo na infância. Nesses termos, parece-me que a formulação de partida foge um pouco do empirismo inerente à reflexão (psico)pedagógica hegemônica.

Neste contexto, afirmo que se alguém declarasse possuir uma solução para essa questão - por exemplo, um método de ensino ou de escolarizaçào, entào, essa pessoa estaria em posse da resposta a um dos mistérios de nossas vidas.

Como assim? Vejamos.

Educar significa metaforicamente endireitar, no sentido de que toda educação visa à colocação em ato de um reconhecimento - o educando é reconhecido, na proporçào do sucesso educativo, como semelhante ${ }^{2}$. Em outras palavras, aquele que educa reconhece o outro, bem como se reconhece a si próprio no outro, visto que o chamado bom educando ao fazer as vezes de um espelho que nos retorna uma imagem em foco de nós mesmos, ganha para si uma marca que o endireita na vida. Diga-se de passagem que, na vida cotidiana, quando predicamos de alguém que "é um mal-educado" estamos afirmando que esse outro nos devolve uma imagem fora-de-foco de nós mes-

Psicanalista; doutor em Educação pela Unicamp. Atualmente é professor do Depto. de Filosofia e Ciências da Educação da USP, e pesquisador do CNPq. 
mos, ao ponto tal de nào podermos nos reconhecer nele, bem como lhe outorgar o estatuto de semelhante.

Assim, poder-se-ia concluir -permitindo-nos certa ligeireza de raciocínio- que "educar uma criança autista ou psicótica" é fazer que ela deixe de ser, precisamente, autista ou psicótica, uma vez que, nào é pouco provável, que perante um autista ou um psicótico venhamos a formular uma pergunta, qual seja: este aqui é gente ou um extraterrestre? A maioria de nós -neuróticos comuns- experimentamos certo espanto perante esses quadros, pelo fato de não podermos reconhecer, nesse que está na nossa frente, um semelhante. Por sinal, é a nào-semelhança desse outro que atiça, até o paroxismo, todo tipo de vocaçào pedagógica ou endireitadora no âmbito da dita educação especial. Isto é, a tentação de converter em familiar esse outro que nos aparece enquanto outro- radical.

Nesse sentido, interrogarmo-nos sobre a escolarizaçào de crianças com DGD é como estar nos perguntando sobre o mistério de como é que nós tornamo-nos aquilo que nós somos, isto é, sujeitos do desejo inconsciente sempre às voltas com o seu reconhecimento simbólico e a "relação" com os semelhantes. Ou, em outros termos, equivale a se colocar a questào da cura do autismo ou da psicose, na medida em que algo da educaçào nestes casos passa pela "conversào" desses outros em neuróticos corriqueiros. Obviamente, estou me permitindo algumas imprecisòes, para assim, poder iniciar nossa reflexào.

Em poucas palavras, caberia afirmar que estamos interessados na educaçào desses que nos aparecem como diferentes, bem como que pressupomos que aquela deve consistir em possibilitar o advento dessas crianças, autistas ou psicóticas, enquanto semelhantes, ou seja, que a educaçào deve visar à instalação da lógica sui generis de funcionamento desejante que define, precisamente, o campo das neuroses -como sabemos, temos o hábito, talvez questionável, de articularmos uma espécie de nosografia psicanalítica tomando como referência o campo da neurose.

Isso posto, podemos dizer que, nesses casos, a clínica analítica e o processo educativo apontam, até certo ponto, numa mesma direçào. Qual? Pois bem, aquela de vir a sustentar o surgimento, aí, onde não há, ou seja, onde deveria haver e não há, um sujeito do desejo -um sujeito do recalque. Assim sendo, estamos, pois, colocando a pergunta acerca das condiçoes necessárias para que a educação venha a ser, neste dominio, uma educaçào terapêutica e nào uma ortopedia (psico)pedagógica 3 .

Cabe assinalar que aquilo que a psicanálise tem a dizer sobre o particular se situa na antípoda do que a(s) psicologia(s) mais ou menos clássica(s) sustenta(m) a esse respeito. Por que? Que papel desempenha a psicologia no campo da educação especial? Ela reclama para si o direito de explicar como o diferente nào é mais do que um desvio psico-maturacional. São as famosas caracterizaçòes e avaliaçòes que permitem predicar com desenvoltura: "este 
é um DV, aquele é um DGD... etc.". Assim, à psicologia competiria dizer do que trata essa diferença, isto é, outorgar uma espécie de conhecimento que possibilite reduzi-la pedagogicamente, pois o objetivo de toda educaçào é fazer da diferença uma semelhança. No entanto, cabe observar que esse é apenas o objetivo visado pela educaçào, pois outra coisa diferente é o que acontece no nível dos resultados.

A educaçà é sumamente paradoxal - aliás, como todo e qualquer processo subjetivo. Ao mesmo tempo que tem por objetivo a fabricaçào de um semelhante, o processo encerra em si mesmo uma limitação. Isto é, gera uma semelhança mas instala, também, uma diferença e, portanto, o educando nunca chega a ser o "educado" que se esperava, pois sempre the faltará um pouco para ser uma réplica de seu mestre circunstancial. Em outras palavras, a educaçào tem por mérito re-inscrever a diferença que estava na origem do processo ou, se preferirmos, em causa no ato educativo.

Se olhamos para trás, através das geraçòes, poderíamos clizer que em alguma coisa todos nos parecemos $e$ em alguma coisa somos diferentes. Entre nossos pais e nós, há algo que permanece, bem como outra coisa que difere.

Pois bem, enquanto todo ato educativo acaba nào podendo menos que articular esse paradoxo, a pedagogia, $e$ mais ainda a pedagogia de nossos dias, pretende a não-presentificaçào, precisamente, desse resto processual. Nesse sentido, afirmamos que a pedagogia é, em termos freudianos, uma grande ilusào, ou seja, uma crença animada por um desejo. Qual? Aquele de fabricarmos cópias ou clones de nós mesmos. Em outras palavras, a pedagogia de hoje e, de forma particular, a pedagogia dita especial - almeja, em última instância, homogeneizar o campo subjetivo desmembrando a lógica educativa, a ponto de visar, sem licença poética alguma, o endireitamento das diferenças ou singularidades psiquicas, ou seja, a fabricaçào de replicantes. No entanto, o processo educativo é inerente à nossa constituição neurótica, uma vez que há alguma coisa da ordem da articulaçào desejante (que, ao tempo que se inscreve como resto, nào cessando de não se realizar em nossa vocação educativa, não cessa de se inscrever nas ilusões pedagógicas. Justamente, as ilusòes pedagógicas têm por função o mascaramento da impossibilidade de todo ato educativo vir a produzir clones, isto é, igualdades no lugar de semelhantes sempre mais ou menos fora de foco. Em resumo, enquanto a educaçào nào pode nào nos assemelhar um pouco,o discurso (psico)peclagógico hegemônico visa a clonagem no real.

Dessa forma, é fácil entendermos o por quê de alguns colegas se autoapresentarem como profissionais que se dedicam, excludentemente, à "pedagogia do DV", "do DA", "do DGD", etc. Fato que ilustra a crença na existência de diferentes formas ou procedimentos para fabricarmos réplicas a partir de diversas realidades ou essências psicobiológicas.

Por que a educaçào especial pressupòe que haveria diferentes procedimentos técnicos dependendo da particular condiçào psico-biológica das crianças? Por que a psicologia pensa que pocle, por sua vez, oferecer à pedagogia algum conhecimento sobre esses estados e, portanto, a possibilidade de formular intervençoes que conduzam à fabricaçào de (pseudo) semelhanças? Porque ambos os campos epistêmicos, tipicamente modernos, acreditam que somos individuos, isto é, organismos que nos adaptamos ao meio na proporção de nossas capacidades matura- 
cionais, bem como do grau de estimulações gratificantes e frustrantes recebidas. Dessa forma, se "fulano é DV", "DM" ou "DGD", por exemplo, supõe-se que estamos em presença de manifestações qualitativamente diferentes das diversas capacidades maturacionais em jogo. Supõe-se que uns devem ter imatura ou atrofiada uma capacidade em especial, enquanto outros uma outra diferente. Temos, então, que cada uma dessas siglas corresponderia a um estado maturacional de partida diferente de alguma das famosas capacidades. Assim, caberia à psicologia avaliar cada caso para verificar se ao campo fenomênico observado lhe corresponde uma ou outra sigla relativa a uma entidade psico-maturacional. Por outro lado, à empresa educativa caberia a tarefa de estimular cada uma das capacidades que se supòem atrofiadas ou retardadas na origem. Por exemplo, a educação dos surdos, desde o final do século passado até poucas décadas atrás, estava, precisamente, centrada na tentativa de resgatar, a qualquer preço e em primeiro lugar, essa diferença sensorial que está na origem ${ }^{4}$. Assim, até que a criança surda nào aprendesse a "falar", ficava suspensa toda iniciativa escolar. Logo, apagada essa diferença, poderia vir o resto: ler e escrever, aprender a calcular, aprender a pôr carta no correio, ir ao supermercado, e assim por diante.

Sendo hegemônico esse raciocínio no campo da educação especial, a diferença entre a educaçào regular e a dita especial passa a ser pensada como da ordem da quantidade das capacidades maturacionais a serem estimuladas, no intuito de conseguir uma homogenização das produções subjetivas, bem como da paciência profissional requerida nessa empresa.

Pois bem, a partir da psicanálise essa forma de raciocinar é questionada, uma vez que é subvertida a noção clássica de indivíduo. Nào há dúvidas de que o organismo possui suas leis biológicas, mas o sujeito do qual fala a psicanálise é outro; como sabemos, esse sujeito é o sujeito do desejo. Desse modo, enquanto a psicologia condena a maioria dos colegas que trabalham em educação especial à quantificação da diferença psico-maturacional supostamente existente entre um "DA", um "DGD", dentre outros, pareceme que a psicanálise nos possibilita re-centrar eticamente a lógica educativa. Isso nào significa que seja sem interesse que alguns, por exemplo, "ouçam" e outros nào, e sem que o desdobramento do processo educativo nào responde a uma lógica maturacional. Os efeitos educativos, isto é, a inscriçào de marcas de semelhança marcas que, à medida que endireitam, assemelham - dependem da possibilidade de virmos a colocar em ato um processo de reconhecimento que carrega em si mesmo a possibilidade de re-inscrever, paradoxalmente, a diferença que está em causa na origem. Educar é vir a sustentar a articulaçào permanente desse paradoxo. Assim, enquanto a pedagogia hegemônica sustenta que a educaçào neste campo deve passar pela estimulação "especial", paciente e metódica, das clássicas capacidades, em virtude do estado matu- 
racional de partida, a subversão possibilitada pela psicanálise nos permite, ao contrário, afirmar que rima com o desejo, na medida em que a díade semelhança/diferença, articulada em todo ato educativo, exprime o paradoxo mesmo do desejo - aquele que alguns filósofos chamam de repetiçào e diferença. Nesse sentido, trata-se, no âmbito que nos ocupa - a educação com crianças autistas e psicóticas - de vir a sustentar o processo educativo aí onde ele, a princípio, nào funciona "automaticamente", na medida em que o dito educando não estaria tomado numa lógica desejante.

Como se constitui o sujeito do desejo? Como pode ser observado, o fato de colocarmos a questào em termos de constituiçào pressupõe que nào é, precisamente, um dado, mas um efeito.

O sujeito do desejo é o efeito de um processo de defesa perante uma falta. Essa falta é aquilo que ecoa como ausência na demanda do Outro. Portanto, o sujeito é o efeito de um processo de agenciamento de saber sobre essa falta no Outro 5 .

Como sabemos, o Outro primordial, que uma mãe sabe sustentar, demanda. Por outro lado, o pequeno se posiciona perante elas. Como? Tentando se alocar como objeto dessas demandas. No entanto, logo coloca-se o problema seguinte: se ele se posiciona apenas como objeto de satisfaçào dessas demandas, isto é, como objeto de gozo desse Outro pulsional ...

* alguém do público intervém e diz: tá ferrado!

$130 \mathrm{~m}$, isso vai depender do desenrolar da história. O que devemos ter claro é que um primeiro destino necessário é colocar-se como objeto das demandas maternas. Justamente, o efeito sujeito será "aquilo" resultante de um processo de defesa perante a demanda, 
isto é, de um processo de anteparo perante o pulsionar do Outro.

$O$ que se afunila nessa série de demandas do Outro primordial? Se o Outro demanda é porque está em falta. Então, aquilo que se afunila no horizonte recortado por essa série de demandas é o fato de que o Outro está em falta, isto é, está castrado. Portanto, se perante as demandas primordiais, $O$ "sujeito" se aloca na posição de objeto, então ele virá a se constituir como sujeito na medida em que se defenda disso que nelas se afunila como sendo o desejo do Outro, a castraçào no Outro. Defender-se é poder agenciar um certo saber sobre o desejo, sobre a falta no Outro. Em outras palavras, é como se o infans dissesse alguma coisa deste teor: "tudo bem, ela não me quer enquanto pedaço de carne; na realidade, quer que seja tal coisa". Isto é, a criança antepòe ao desejo do Outro uma espécie de coágulo de saber. O outro nào lhe quer enquanto pedaço de carne, ou seja, a sua condição objetal nào basta. O Outro quer determinadas produçòes imaginárias, quer que venha a dar sustentaçà a determinadas insígnias fálicas.

Então, podemos afirmar que o sujeito do desejo resulta da defesa perante a demanda. Mas o problema é o seguinte: de onde o sujeito que se constitui enquanto tal retira esses retalhos de saber inconsciente para poder agenciar uma resposta singular a respeito do que o Outro quer dele? Pois bem, nào pode tirar um saber do seu próprio umbigo, ou seja, nós nào trazemos uma carga genética de saber nesse senticko. Justamente, o sujeito extrai e recorta esses saberes parciais para poder construir uma resposta ao desejo do Outro, resposta que funcione como um anteparo, que aponte a uma modalizaçào da demanda. Seria como se a criança dizesse "pare aí!... nào me seqüestre, eu vou the dar outra coisa, aquilo que você quer, vou fazer tal coisa...". Isso é interessante, porque o mesmo Outro que demanda é quem outorga também os retalhos de saber, ou seja, que dôa significantes, matéria prima do saber inconsciente. Em resumo, é esse quem "ensina" ao pequeno como se arranjar com o desejo.

Ensinar é colocar em signos, isto é, é mostrar. Assim, o Outro que demanda, mostra, sem saber, quais são as cartas. Em outras palavras, o Outro "coloca" à disposição do pequeno os significantes para que construa um saber, uma ficçào. Um saber ficcional sobre essa origem, sobre como responder a esta demanda do Outro. No entanto, não devemos esquecer que o Outro tem que pedir e também ofertar.

O Outro transmite uma amostra de saber que marca para a criança os limites de um lugar possível. Assim, o ensinado funciona como uma marca, um traço. Na medida em que o pequeno pega este traço, gruda-se a ele, ou seja, aliena-se nesse traço que o assemelha ao adulto que encarna o Outro. $O$ assemelha na medida em que responde parcialmente à demanda deste Outro. $\mathrm{O}$ problema é que na tradução ou na transcriçào deste traço de "um lado" do campo do Outro para "um outro lado" cai um resto. Como sabemos, em toda traduçào de uma língua para outra há uma perda. Esse resto é, precisamente, a diferença.

Resumindo, em toda tentativa de transmissào alguma coisa se transmite; mais ainda, o transmitido - um traço -, assemelha, endireita. isto é, educa, endireita àquele que aparece como diferente, torna-o semelhante; porém, numa outra instância o torna diferente, pois () saber, agenciado por aquele em posiçào de educando, revela-se parcial, ou seja, nào constitui uma resposta conclusiva à pergunta pelo desejo do Outro. Assim temos que o sujeito, efeito da 
operaçào de defesa da falta no Outro, leva consigo a diferença que estava no ponto de partida. A diferença se reinscreve ad infinitum ou como diria Deleuze, desdobra-se.

Estamos nos perguntando por aqueles que nos aparecem como totalmente diferentes, que habitam o mundo segundo uma outra lógica subjetiva. $\mathrm{Ou}$ seja, sobre como fazer para eles entrarem numa lógica desejante neurótica, de como seria possível vir a sustentar um dispositivo educacional que opere a passagem do campo da psicose para o da neurose. Justamente, se alguém dissesse possuir uma fórmula técnica para resolvermos essa questão, entào, teria desvendado o mistério de como vir, em última instância, a fabricar vida humana.

A psicanálise afirma, ao contrário da psicologia, que nào há nenhum método que garanta essa fabricação, que nào podemos saber a priori o destino de toda e qualquer empresa subjetiva. Como sabemos, existe uma série de métodos para garantir a gestação (pode ser de proveta, de aluguel), mas não uma seqüência de passos técnicos para gerarmos subjetividades desejantes. No entanto, a psicanálise pode, sim, esclarecer-nos sobre aquilo que não devemos fazer no campo educativo.

Justamente, parece-me que a Ecole Expérimentale de Bonneuil-sur-Marne está pensada a partir dessa idéia.

Nessa instituição, fundada por Maud Mannoni em 1969, não se faz psicanálise, embora tudo o que faz esteja inspirado por ela. Entào, temos que a psicanálise inspira um projeto educativo, porém não pedagógico. Essa inspiraçào é a subversào radical da lógica pedagógica moderna. O subvertido é, precisamente, essa idéia de sermos individualidades psico-biológicas à espera de metódicas estimulações mais ou menos gratificantes. Assim, o desafio é sustentar uma instância educativa renunciando à noçào de individuo em torno da qual gravitam todas as ilusoes pedagógicas. Em suma, trata-se de sustentar uma experiência subjetivante sendo, apenas, educadores e não pedagogos.

Pois bem, minha intenção é justificar o caráter singular do dispositivo institucional valendo-me daquele pequeno algoritmo que estaria no cerne do campo do desejo. Em outras palavras, assinalar como o funcionamento institucional de Bonneuil torna possível a articulação do sujeito do desejo, como efeito de uma operaçào de defesa perante a demanda objetivante do Outro.

O lema que sustenta o cotidiano em Bonneuil é "um lugar para viver". Lema que reaparece com uma pequena diferença no nome da Pré-bscola Terapêutica Lugar de Vida.

Qual é a idéia básica? Por que Bonneuil é uma escola e não uma clínica mais ou menos clássica? Trata-se de um lugar, aberto à recepção de todos aqueles expulsos do sistema francês de ensino, onde nào se administram cuidados -sejam eles médicos, psicológicos, psicanalíticos, psiquiátricos, fonoaudiológico, etc.. Nesse sentido, caberia afirmar que Bonneuil é, paradoxalmente, "mais escola" que até muitas escolas ditas normais de hoje em dia. Como sabemos, existem escolas que se apresentam ao mercado pedagógico pelos serviços para-educativos de que dispòem. Assim, dizem possuir fonoaudiólogos, psicólogos, psicopedagogos, orientadores para tal fim ou tal outro, etc. A presença desses profissionais teria como fim garantir o sucesso da empresa educativa. Parece que a presença desses saberes funciona como uma garantia extra. Que reivindicam para si cada um desses campos profissionais? A potestade de vir a estimular, 
de uma forma especializada, alguma das ditas capacidades maturacionais -ponto de arranque de toda educação. Assim, um "estica" a língua, outros, a vontade, a memória, a atençào, a criatividade, etc.. Mais ainda, pensa-se que na medida em que cada um "estica" mais ou menos sincronizadamente com os outros, a educadora/pedagoga pode fazer o serviço dela "por fora". Isso é um ponto digno de ser destacado, pois as crianças que freqüentam Bonneuil são todas mais ou menos "a-normais". Aliás, tão fora da norma que a maioria de nossos colegas poderia "realizar-se" profissionalmente.

Bonneuil inverte, precisamente, a lógica pedagógica hegemônica. Dessa forma, enquanto se pensa que "essas" crianças devem ser "esticadas" para assim serem educadas, Mannoni propòe, simplesmente, "uma educação para todos". É como se clissesse "aqui não se estica, criam-se as condiçòes para que algo da ordem da educação possa advir". Trata-se de sustentar um Outro primordial "esburacado" -não o Outro perverso da pedagogia hegemônica- doador de significantes, que possibilitem a queda de um sujeito como efeito de um saber sobre o desejo que se afunila em toda demanda educativa. O dispositivo institucional de Bonneuil responde a essa tentativa e o conceito de instituição estillaçada indica, precisamente, essa direçào de trabalho.

Por sinal, permito-me traduzir " $e$ clatée" - termo que Mannoni utiliza para qualificar o dispositivo institucional- por estilhaçada, no lugar de estourada, como proposto habitualmente. Vejamos.

O que é que se estilhaçam? Os espelhos. Como sabemos, o que está em questão nestes quadros clínicos é alguma coisa da ordem da experiência especular: ou são vicissitudes pré-espelho, ou são vicissitudes inerentes ao próprio jogo especular. Por outro lado, lembremos que os movimentos anti-psiquiátricos italianos e ingleses - reconhecidos por Mannoni como fontes inspiradoras- assinalaram que os psicóticos, em geral, acabam se dando muito bem com as instituições perversas. Os paranóicos têm um prato cheio: nos manicômios sempre encontram alguém que os persegue. Aliás, eles têm razào. Há um dito popular que sentencia: os bêbados, os malucos e as crianças sempre dizem a verdade! Pois bem, a psiquiatria é uma grande perseguidora. Ora, os autistas e catatônicos também acabam sendo "felizes" nos asilos, pois nada "melhor" que se oferecer como objeto de gozo para o Outro. Entào, em Bonneuil -reconhecendo esse impasse institucional- trata-se, precisamente, de estilhaçar a miragem especular inerente ao dispositivo manicomial. Assim, Bonneuil posiciona-se como um espelho que tem um furo no centro, ou seja, é uma instituição que, ao contrário das instituições psiquiátricas e pedagógicas clássicas, dispõe-se ofertar, apresentando-se em falta. Única e paradoxal possibilidade - assim sendo antimetódica- de virmos a sustentar as condiçòes para que alguma coisa da ordem do sujeito possa advir.

Pois bem, onde está o "buraco" nesse dispositivo institucional chamado Bonneuil?

Observo -para aqueles que nào estão familiarizados- que Bonneuil se reduz apenas a dois pequenos sobrados na periferia de paris (a cidade de Bonneuil-sur-Marne), separados no meio por um vizinho. Trata-se de duas casas muito pequenas e simples. Nào parecem com uma "instituição" ou qualquer um dos centros especializados que estamos acostumados a ver. É como se fossem duas moradias, Aliás, trata-se, justamente, de "um lugar para viver"... Para viver educadamente! Qual é o dis- 
positivo ou a lógica que torna possível a vida do desejo? Bonneuil constitui-se como "um lugar para viver", pois articula-se sobre uma proibição.

O cotidiano em Bonneuil consiste na realização de uma série de tarefas educativas: fazer a comida, comprar pão, limpar a casa, aprender espanhol, italiano, matemática, às vezes francês, contar contos, aprender música e assim por diante. Isto é, no dia-a-dia as crianças realizam coisas que qualquer outra criança e adulto podem fazer na vida cotidiana. Nâo há mistério algum nas tarefas. O traço singular de Bonneuil não passa pela oferta educativa. Isso é interessante de ser assinalado, pois é hábito encontrarmos pessoas que pensam que o distintivo passa pelo fato de as crianças freqüentarem uma série de ateliês onde se fariam coisas muito extraordinárias. Assim dito, dá-se a entender que as atividades realizadas tiram as crianças da psicose. Obviamente, o que está em questào nào é nada da ordem de uma labor-terapia. Em principio, qualquer intervenção pode vir a ter efeitos subjetivantes aliás, sâo os behavioristas que pensam que há a priori coisas mais "estimulantes" que outras. Aquilo que caracteriza Bonneuil é a decisào de manter, em todo tipo de circunstâncias, a operatividade de uma proibiçào -a proibição do incesto, isto é, a proibição da miragem perversa, a proibiçào de fazer do outro um objeto de gozo. Ou, como se diz em Bonneuil - oncle nào se fala com as crianças em lacanês, pois não seria bom para a educação delas"o homem nào pode ser o lobo do homem".

Como sustentar no dia-a-dia esta proibição, uma vez que partimos do pressuposto de que ela nào impera no campo da psicose e do autismo, no intuito de que possa advir alguma coisa da ordem do sujeito do desejo? 
Neste ponto, recuperamos a interrogação acerca do impasse inerente à educação. A educaçào é possível porque o Outro acaba, em última instância, renunciando, a fazer do outro o seu objeto de gozo. Em suma, o Outro opera um desmentido - "dénégation"sobre a sua demanda educativa.

O campo da neurose é o recalque, isto é, o recalque da diferença, da castração, do desejo... de uma pergunta - o Outro, o que quer de mim? Assim, para que o sujeito venha a se constituir como efeito do recalque desse interrogante, o Outro deve desmentir sua demanda -"eu te peço isto, mas nào é muito bem isso que eu quero". Desmentir, dizer uma mentira do tipo: "eu gostaria que você faça isso, mas em última instância, eu não vou morrer se você fizer o contrário". Esse espécie de oxigênio que o Outro insufla na sua própria demanda permite ao "sujeito" constituir-se como efeito de um saber sobre essa demanda. A essa operação de desmentido, corresponde, do "outro lado", o recalque. O que se recalca? Recalca-se a diferença que se perfila entre o dito e o desmentido, ou seja, um nào-saber.

Lembremos que Freud sustenta que a denegação é aquele mecanismo graças ao qual um sujeito formula um de seus desejos, embora continue negando que lhe diga respeito - a clássica formula: "o Senhor vai pensar que é isto, mas não é". Isso posto, cabe observar que é uma certa forma de ter acesso a algo recalcado. O que se afirma e se nega na "dénégation"? No jogo da afirmaçàonegaçào articula-se algo da ordem de uma diferença. Diferença que, precisamente, o Outro desdobra quando desmente a sua própria demanda -"nào é muito bem isto que eu queria, queria outra coisa".

Dessa forma, se entendemos que esses mecanismos articulam o campo do Outro, então se poderia concluir que o dispositivo educativo deve recriar a dupla desmentido-recalque. Pois bem, o que isso tem a ver com os ateliês? Com as tarefas corriqueiras desenvolvidas em Bonneuil? Vejamos. É fácil observar que são tarefas cotidianas, ou seja, atividades que definem o cotidiano de uma cultura dada. Nesse sentido, bem se poderia ilustrar o postulado mannoniano apelando para essa clássica expressão: cultura neles! No lugar de dizer: estimulaçào neles! Interessante de ser salientado, pois a pedagogia especial propòe de fato uma série de atividades a fim de "estimular" uma ou várias habilidades psico-orgânicas, para assim, dependendo dos resultados obtidos, "inserir" a criança na vida cotidiana. É sabido que as crianças com síndrome de Down devem, por exemplo, diferenciar, primeiro, o verde do amarelo, para assim poder aprender depois que a letra $M$ é o $M$ com a qual escrevemos mamàe. Em suma, sempre pensam as intervençoes "educativas" sob a lógica da estimulação de habilidades.

Em Bonneuil entende-se por cultura desde tirar o capim do jardim, cultivar batatas, dar descarga no banheiro ou participar das atividades que o Musée du Louvre costuma ofertar para todas as 
crianças. Por que? O que está em questão na transmissão desses savoirviver?

Quando ensinamos algo para uma criança, acontecem duas coisas. Por um lado, colocamos em ato nossa fantasmática, isto é, a inciativa do ato cai na conta do desejo do adulto. Por outro, transmite-se uma lógica operativa que transcende o campo fantasmático no interior do qual estamos singularmente tomados, uma vez que se trata de um pedaço da cultura, um universal, um fragmento de liame social. Em suma, à medida que a criança "apre(e)nde" a amostra de laço transmitida, faz laço.

$O$ cotidiano em Bonneuil aponta à sustentaçào da possibilidade de as crianças virem a fazer laço. O que "gruda"? O que enlaça é o desejo do adulto, em posição de educador, mas também o próprio fragmento interativo transmitido. O que se transmite? Uma forma de colher batatas, uma forma de lavar a louça, de brincar, de lidar com isso chamado dinheiro. Nisso "outro" que se transmite ecoa uma dimensão outra que estilhaça, precisamente, a miragem adulto-criança. Entre o adulto e a criança medeia um fragmento cultural. Assim, temos o espelho estilhaçado. Portanto, em Bonneuil se evita a montagem de um dispositivo perverso. Em outras palavras é como se se dissesse para as crianças "você nào faz por que eu quero, você faz assim porque é dessa forma que todos devemos fazer se quisermos manter vivo esse pedaço de cultura".

* Questão do público: Isto não tem a ver com a noção de identidade?

Quer dizer que se nessa transmissão haveria algum efeito de identidade? É claro! Por isso disse que o objetivo da educação é fabricar semelhantes, para assim, pudermos nos reconhecer, até certo ponto, como idênticos. Caso contrário, por que estaríamos juntos? Ve- jamos. Se pensasse que vocês são marcianos, iria embora, pois confesso-lhes que tenho medo de extraterrestres. No mínimo, tenho que reconhecer que somos semelhantes, mas também diferentes. Se fôssemos, de fato, idênticos, não falaríamos entre nós. Por que? Nós falamos para arrancar do outro/Outro alguma coisa, um certo saber sobre o desejo. Obviamente, há desejo - uma diferença irredutível - porque nào somos iguais, embora sejamos semelhantes. Isso posto, não há dúvida que se trata, efetivamente, de instaurar algo da ordem das identidades. Tratar-se-ia de imprimir certas insígnias identitárias. Justamente, a psicanálise nos ensina que se quisermos isso no trabalho com crianças autistas e psicóticas, então, não devemos montar um dispositivo perverso, pois se ofertarão como objeto. A única forma de colocarmos um limite à nossa vocação igualitária é "colocarmos cultura no meio". À medida que a relação cotidiana entre o adulto e a criança está perpassada pela obrigação de jogar com as regras da cultura, a instituiçào se estilhaça evitando que o pequeno ocupe a posição de objeto de gozo do adulto-Outro. É como dizer para as crianças: não queremos vocês, queremos outra coisa que é alter. Em outras palavras, "eu não sou o todo da cultura, apenas sou mais um".

O segredo de Bonneuil é isso. Um grupo de adultos que fazem, às vezes, coisas muito divertidas, no intuito de dar sustentação ao laço educativo quando se trata de crianças consideradas resto pelo sistema escolar tradicional. Assim, a questão não passa por inventar ateliês nas escolas tradicionais -Ah! Depois de passar horas a fio, repetindo "verde... amarelo", agora, vamos ao ateliê de música! Não se trata disso.

O estilhaçamento da instituição se produz também com o sistema singular 
de acolhida das crianças por famílias do campo - les familles d'accueil -, bem como pelo fato de a moradia estar des-centralizada - les lieux d'accueil. A escola, em si, ocupa dois sobrados, mas a "escola" se estende até onde vai a transferência que o significante Bonneuil convoca. Algumas crianças vivem nas moradias que a escola possui em Bonneuil ou Créteil, outras com seus próprios pais ou com famílias camponesas. Obviamente, essa decisào, aliás, como todas, são pensadas singularmente. Isto é, nào há regimentos administrativos destinados à instituiçào de uma generalização. O importante é que, seja onde for, as crianças sempre moram em "casas", ou seja, em lugares tomados por uma lógica caseira.

Por que as famílias que conforman essa rede de familles d'accueil são famílias rurais, famílias de cidades ou vilarejos perdidos no interior da França? Que fazem as crianças clurante o tempo que passam com elas? Trabalham naquilo que a família trabalha. Se fabricam queijo, a criança também fabrica queijo, se nessa familia o senhor é pedreiro, a criança também trabalha de pedreiro... Alguém poderia dizer: "pois bem, qual é o rendimento dessas crianças?" Típica pergunta de psicólogo ou pedagogo tradicional! Essa pergunta está proibida! Nào se visa à performance. Mais ainda, o objetivo não é uma aprendizagem profissional, embora haja algumas crianças que acabem aprendendo algum ofício. O fundamental é provocar, justamente, a constituiçào de um "outro lugar" que nào os dois sobrados, para estilhaçar a instituiçào. Assim, a criança está em Bonneuil, mas nào está; estuda em Bonneuil, mas está no campo criando vacas.

As crianças podem passar alguns meses com as familles d'accueil e regressar o final de semana, podem morar com os pais mas viver de Segunda à
Sexta-feira nas maisons d'accueil. Enquanto algumas crianças podem estar na escola no período das nove da manhà às quatro e meia da tarde - fazendo italiano, cozinhando ou realizando a tarefa de francês-, outras podem estar colhendo alfaces no horto do vizinho. Em suma, em Bonneuil todo mundo pode estar em qualquer lugar, sentindose partícipe de Bonneuil.

Bonneuil opera como o significante que coloca todos em posição de trabalho. As pessoas não fazem seu capricho, fazem aquilo que a lógica do trabalho as obriga a realizar. Bonneuil é um lugar que nos desafia a viver sem atrapalhar a vida dos outros.

Quando de meu estágio em Bonneuil, participei um certo tempo do grupo escolar para crianças muito pequenas ${ }^{6}$. Muitas vezes, tratava-se apenas de cantar uma ou duas músicas infantis populares. O grupo podia ser de quatro crianças e três ou cinco adultos. Tratava-se de formar uma roda na qual, de mãos dadas, alguém perguntava o que iríamos cantar, quem queria marcar o ritmo... Pois bem, talvez álguém deva estar se perguntando até que ponto era possível manter uma rodinha com crianças psicóticas e autistas.

Justamente, neste ponto devemos lembrar uma frase que Manonni gosta de repetir: "a única coisa que pedimos às crianças é que façam de conta que sào normais". Cabe observar que não se pede para elas serem normais, mas para fazerem de conta. Trata-se de uma demanda que se articula no desmentido.

$\mathrm{O}$ que fizemos naquelas circunstancias? Fazíamos de conta que éramos todos normais. Aliás, em Bonneuil se faz de conta que as crianças sào adultas, ou se preferirmos, responsáveis. Dentre outras razòes, é por isso que as crianças "trabalham". Essa é uma outra forma de subverter a pedagogia, pois ela infantiliza. Como sabemos, a 
criança é um efeito da pedagogia moderna.

Voltemos àquela roda normal! Pode-se perguntar: "quem começa?" Algumas vezes, alguma criança balbucia algo e o adulto toma isso como a resposta. O adulto diz: "Ah!... você disse que quer começar, vamos, marque o ritmo!" Alguém dos presentes pode muito bem colocar em dúvida a natureza da "resposta" infantil. Entretanto, a questào nào passa por á́. 'Tratase de que "o show deve continuar". Todo mundo faz de conta que o ritmo está sendo marcado, canta-se... A tarefa do adulto é manter a cena que encena um laço.

Certa vez aconteceu - foi uma dessas manhãs "terriveis"- que algumas crianças foram desfazendo logo a roda: uma jogou-se no chão, a outra abriu a porta e desceu escada abaixo, uma outra chorava aos berros. Em circunstâncias como essas, um adulto pode acompanhar quem desceu pelas escadas, um outro pode exclamar: "Ah, não está cantando a música, você deve ter esquecido, vamos cantar juntos". Observemos que não se trata nem das pretendidas interpretações psicológicoanalíticas, nem comentários pedagógicos do tipo "está além das suas capacidacles". Ao contrário, trata-se de manter o cenário do "fazer de conta". Aí é que está o feeling do adulto, de como se mantém na transferência. Pode ser o caso de continuar a cantarolar a música nas escadas. No entanto, a intervenção nunca deve acenar com a possibilidade de que alguém possa deixar de participar por atrapalhar o empreendimento dos restantes. Àquele que boicoteia é lembrada a Lei de diferentes formas. Por exemplo, "olha, você não está nos deixando cantar, estamos nos divertindo muito aqui, se você não quiser, tudo bem, não participe, mas não atrapalhe. Se você continuar atrapalhando, a gente bota você prá ford. Você escolhe".

Chegados a este ponto, alguém pode perguntar-me: "mas vocês tinham certeza se tal intervenção teria os efeitos esperados?" Obviamente, nunca se tem certeza. Essa é a regra. De fato, tenho visto muitas crianças abandonarem a sala onde estávamos cantando. $\mathrm{O}$ interessante é que ninguém toma conta da criança. Às vezes, elas acabam se encontrando e brincando sozinhas num outro canto da casa, sem ninguém se preocupar. É também bom lembrarmos que as portas dos dois sobrados nào têm chaves e, entretanto, não há na história de Bonneuil registro de que uma criança tenha se perdido ou tenha sido atropelada na rua.

Pois bem, certo dia nós, os adultos, fomos, de fato, abandonados. Vimo-nos sorrindo, pois éramos quatro adultos, agarrados pelas mãos, cantando uma música infantil. Cantamos até o final, realizamos o pequeno ritual de encerramento da atividade grupal e a demos por encerrada. Por que mantivemos a situação? Porque a manutenção desse fragmento cultural supòe a existência de um terceiro. Em suma, trata-se de uma tentativa esforçada para manter sempre a referência a um terceiro. Aliás, é precisamente por isso que grande parte das atividades se realiza fora dos muros de Bonneuil. Por exemplo, as crianças freqüentam a piscina pública no horário normal, como qualquer outra. Ou seja, não há um horário para as "deficientes" nadarem metodicamente. É fácil? Não, não é "fácil" acompanhar quatro, cinco ou meia dúzia de crianças. Esse gesto anti-asilar abre margem para todo tipo de imprevistos. $O$ que costuma acontecer? Pois bem, as típicas coisas que acontecem quando se está com crianças não muito educadas.

Justamente, é o inverso do que acontece nas escolas e nos estabelecimentos de educação especial, onde se 
convoca qualquer "saber científico" para obturar a pergunta que se aninha na diferença: o que quer o outro de mim? Assim, fabricam-se casos. No entanto, um sujeito é antinômico com a fabricaça de todo caso. Por isso, em psicanálise devemos renunciar à pretensào de fabricar explicaçoes claras e distintas. Nesse mesmo sentido, os educadores de Bonneuil sabem também do nosso limite explicativo. Mais ainda, por saberem sabiamente isso, estào sempre prestes à invençào do cotidiano, ou seja, dispostos a não fazer do imprevisto um incidente - um desvio a respeito de uma norma. Aliás, Basaglia já assinalara que a lógica da psiquiatria aponta, precisamente, para a conversào dos imprevistos em incidentes.

Assim sendo, podemos muito bem concluir que a pedagogia especial consiste em fazer dos imprevistos educativos incidentes psicopedagógicos inerentes à escolarizaçào das "crianças DGD".

\section{NOTAS}

1 Versào corrigida e parcialmente modificalda pelo autor da aula proferida, sob o mesmo título, em 18 de novembro de 1997, no contexto do Curso de Aperfeiçoamento Novas Tendências no Tratamento da Criança com Distirbios Globais do Desenvolvimento, promovido pela Pré-Escola Terapêutica Lugar de Vicka-USP. A transcrição da fita gravada na época foi realizada por Cynthia de Medeiros (doutoranda FEUSP).

2 Fssa conceitualizaçào foi desenvolvida detalhadamente no texto Dos "erros" e em especial daquele de renunciar à educaçào. Notas de psicanálise e educaçào publicado em Estiles da Clínica, Ano 2, $\mathrm{N}^{*} 2$, pp. 27-43, 1997. Por ocasião da aula - açui transcrita- ministrada com antecedência à redaçăo desse texto, a mesma foi apresentada tanto parcialmente quanto com rapidez. Assim sendo, para maiores precisoes sobre o desenvolvimento que se segue à continuacào, remetemos os keitores àquele texto.

3 Para maiores esclarecimentos consultar: Kupfer, M-C. Educação Terapêtutica: o que a psicancilise deve pedir à educaçào in Estilos da Clinica, N"2, pp. 53-61, 1997. Jerusalinsky, A. La educación, jes terapéutica? in Escritos de la Infancia, N* 5, pp. 11-18, 1995.

4 cf. de Lajonquière, L. Deficiências Sensoriais 'Subjetividade. Notas Criticas à Ideologia Reabilitadora In Educaçào \& Sociedade, No 48, pp. 304-325, 1994.

5 Para maiores detalhes a propósito de saber sobre, saber de c o caráter nào-sabido do satber inconsciente, remeto os leitores a meu texto Dos "erros" e em especial daquele de renunciar à Educaçaio e em especial àquele intitulado A criança, "sua" (in)disciplina e a Psicanálise publicado In Aquino, J. (Org.) (1996) A Indisciplina na Escola, Sào Paulo: Summus, pp. 25-37.

${ }^{6}$ Estágio pós-doutoral, realizado com auxílio do CNPq durante os meses de Janeiro e Fevereiro de 1995. 